\title{
Stress-dependent undrained shear behavior of remolded deep clay in East China*
}

\author{
Xiang-yu SHANG ${ }^{\dagger 1,2}$, Guo-qing ZHOU ${ }^{1}$, Yong $\mathrm{LU}^{3}$ \\ ( ${ }^{1}$ State Key Laboratory for Geomechanics and Deep Underground Engineering, \\ China University of Mining and Technology, Xuzhou 221116, China) \\ $\left({ }^{2}\right.$ School of Mechanics \& Civil Engineering, China University of Mining and Technology, Xuzhou 221116, China) \\ ( ${ }^{3}$ School of Civil Engineering, Suzhou University of Science and Technology, Suzhou 215009, China) \\ †E-mail: xyshang@cumt.edu.cn
}

Received Aug. 27, 2014; Revision accepted Dec. 23, 2014; Crosschecked Feb. 26, 2015

\begin{abstract}
Consolidated-isotropically undrained triaxial compression (CIUC) tests were performed on the reconstituted deep clay from a mine in East China. It was consolidated to maximum stresses in the range of 0.3-2.6 MPa. The test results show that the stress-strain-strength properties of the clay during undrained shear are significantly stress-dependent. In particular, in the case of high consolidation pressure, the post-peak drop in strength on stress-strain curves and shear plane in soil specimens are more evident, the peak stress ratio and the axial strain at which this ratio was reached are smaller, and the relationship between pore pressure and axial strain is also significantly different from that for the case of low consolidation pressure. The environmental scanning electron microscope observations and micro analysis lead to an understanding of the physical mechanisms underlying the above stress-dependent mechanical behavior. In addition, the CIUC behaviors of the studied clay are discussed in the context of critical state soil mechanics.
\end{abstract}

Key words: Deep clay, High pressure, Undrained triaxial compression, Stress-dependent behavior doi:10.1631/jzus.A1400255 Document code: A CLC number: TU41

\section{Introduction}

There are over one hundred vertical mine shafts in East China, most of which are buried in the Quaternary overburden with an average thickness of over $200 \mathrm{~m}$. The load distribution on a several-hundredmeter-long shaft lining was usually determined empirically during the design phase (Cui, 2003). This increased the risk of rupture in shaft linings ( $\mathrm{Li}$ and $\mathrm{Li}, 2005)$. The unclear load distribution is due to the fact that the mechanical properties of deep soil, especially the deep clay, have not yet been fully under-

\footnotetext{
* Project supported by the National Natural Science Foundation of China (No. 51009136), and the Ministry of Science and Technology of China (No. 2012CB026103)

(DD ORCID: Xiang-yu SHANG, http://orcid.org/0000-0003-738-2424 (C) Zhejiang University and Springer-Verlag Berlin Heidelberg 2015
}

stood. However, the inevitable sample disturbance and high cost of sampling make it very difficult to obtain a large amount of high quality undisturbed deep clay samples for thorough study (Xu, 2004; Ma et al., 2008). As a preliminary step in developing the understanding of these deep soils, it is necessary to study the mechanical properties of the saturated remolded deep clays at a wide range of consolidation stresses (Ma et al., 2008; Zhao et al., 2009).

So far, very few experimental investigations have been carried out on stress-dependent behaviors of saturated clay among which the maximum consolidation stresses were above $2 \mathrm{MPa}$. Graham et al. (1990) reported on isotropically consolidated undrained triaxial compression (CIUC) tests at confining pressures in the range of $0.2-3.0 \mathrm{MPa}$ on the saturated artificial Canadian reference buffer material (RBM) which is a 50/50 mixture of sand and 
Na-bentonite. They showed that the normalized stress-strain, pore pressure, and shear strength for test with confining pressure being $0.2 \mathrm{MPa}$ were different from those for the $3 \mathrm{MPa}$ test. Abdulhadi et al. (2012) conducted $\mathrm{K}_{0}$-consolidated undrained triaxial compression tests $\left(\mathrm{CK}_{0} \mathrm{UC}\right)$ on resedimented Boston blue clay (RBBC) consolidated to maximum vertical stress in the range of $0.15-10 \mathrm{MPa}$ at three overconsolidation ratios. They stated that the stress-strain-strength properties at high pressures were different from the counterparts at low pressures (vertical effective stress $\leq 1$ MPa mentioned therein). Zhou (2009) carried out high-pressure CIUC tests on remolded clay (XZ clay) taken in the shallow strata at $12 \mathrm{~m}$ depth in East China, but tests at confining pressures below $2 \mathrm{MPa}$ were not conducted. CIUC tests on remolded deep clay at high pressure have been carried out (Ma et al., 2008; Zhao et al., 2009). However, these tests did not ensure the saturation of the soil specimen and the variations of pore pressure during shear were not presented. The major limitation of these tests is lack of control over the effective stresses in the specimens. Moreover, tests at low confining pressures were not carried out. Therefore, there have not been full CIUC tests on remolded natural clay subjected to a wide range of confining pressures. There are two approaches to improve the reliability and safety of the system to block the failure.

To investigate the influence of confining pressures on the stress-strain- strength properties, we performed CIUC tests on the remolded deep clay from a mine in Shandong Province in East China. In these tests, confining pressures ranged from $0.3 \mathrm{MPa}$ to $2.6 \mathrm{MPa}$ which are equivalent to the burial depths of overburden from around $16 \mathrm{~m}$ to $140 \mathrm{~m}$. Since critical state soil mechanics are recognized to be suitable for the normally consolidated clay (Schofield and Wroth, 1968) and the microscopic water-clay links play an important role in determining the mechanical properties (Zhang, 2011), the stressdependent behaviors of the remolded deep clay in this study and the relevant physical mechanism will be discussed in these two contexts. The results provide an insight into the effects of confining pressures on the undrained shearing behaviors of remolded deep clays.

\section{Materials and methods}

\subsection{Characteristics of clay and specimen preparation}

The clay used in this study was taken from a mine in East China at a depth of about $600 \mathrm{~m}$. Table 1 presents the index properties of the clay. According to the plasticity chart defined in the Chinese specification of soil test (MWR, 1999a), it falls into the category of high liquid limit clay. The quantitative X-ray diffraction analysis of the deep clay shows that it contains $45 \% \mathrm{Na}^{+}-\mathrm{Ca}^{2+}$ smectite, $6.5 \%$ illite, $8.8 \% \mathrm{I} / \mathrm{S}$ (illite/smectite interstratified minerals), 20\% quartz, and so on. Such a mineralogical composition implies that there exists a strong water-clay interaction in the saturated deep clay.

To facilitate the comparisons in subsequent sections, the index properties and the corresponding mineralogical compositions of both the studied clay and several clays mentioned in Section 1 are presented in Table 1.

Each specimen has a height of $12.5 \mathrm{~cm}$ and a diameter of $6.18 \mathrm{~cm}$. Specimen preparation followed a two-step procedure. In the first step, air-dried clay was carefully compacted in five layers into a split

Table 1 Index properties and mineralogical compositions of clays

\begin{tabular}{ccccccc}
\hline Clay & $\begin{array}{c}\text { Clay fraction } \\
<5 \mu \mathrm{m}(\%)\end{array}$ & $\begin{array}{c}\text { Liquid limit } \\
W_{\mathrm{L}}(\%)\end{array}$ & $\begin{array}{c}\text { Plastic limit } \\
W_{\mathrm{P}}(\%)\end{array}$ & $\begin{array}{c}\text { Plasticity } \\
\text { index, } I_{\mathrm{p}}\end{array}$ & $\begin{array}{c}\text { Specific } \\
\text { gravity, } G_{\mathrm{S}}\end{array}$ & $\begin{array}{c}\text { Mineralogical } \\
\text { compositions }\end{array}$ \\
\hline This study & 47.6 & 51.9 & 23.7 & 28.2 & 2.72 & $\begin{array}{c}45 \% \mathrm{Na}^{+}-\mathrm{Ca}^{2+} \text { smectite, } 6.5 \% \\
\text { illite, } 8.8 \% \mathrm{I} / \mathrm{S}, 20 \% \text { quartz }\end{array}$ \\
$\begin{array}{c}\text { RBBC (Abdulhadi } \\
\text { et al., 2012) }\end{array}$ & $56 \pm 1^{*}$ & $46.6 \pm 0.9$ & $23.5 \pm 1.1$ & $23.2 \pm 1.2$ & 2.81 & $\begin{array}{c}\text { Illitic glacio-marine clay } \\
\text { RBM (Graham } \\
\text { et al., 1990) }\end{array}$ \\
$\begin{array}{c}\text { XZ clay } \\
\text { (Zhou, 2009) }\end{array}$ & - & 250 & 50 & 200 & - & $\begin{array}{c}\text { Bentonite contains } 80 \% \text { sodium } \\
\text { montmorillonite, } 10 \% \text { illite }\end{array}$ \\
& $19 \pm 1$ & - & - & - & - & $\begin{array}{c}45 \% \mathrm{I} / \mathrm{S}, 26 \% \text { illite, } 10 \% \\
\mathrm{Na}-\mathrm{Ca}^{2+} \text { smectite, } 8 \% \text { chlo- } \\
\text { rite, } 7 \% \text { Kaolinite }\end{array}$ \\
\hline
\end{tabular}

\footnotetext{
Clay fraction $<2 \mu \mathrm{m}$
} 
mold, which has the same size as the specimen, to ensure that the sample has a dry density of $1.453 \mathrm{~g} / \mathrm{cm}^{3}$. In the second step, the specimens within the split mold absorbed distilled water in a vacuum chamber for $24 \mathrm{~h}$. After that, the soil specimens should effectively achieve a high degree of saturation. According to the designed dry density and specific gravity of the clay, the measured water content of prepared specimen was very close to $32 \%$, which guarantees a high saturation degree of over $98.5 \%$.

Note that the above specimen preparation will unavoidably result in pre-consolidation pressure in the specimens. A series of oedometer tests were carried out on the clay specimens which had been prepared using the above technique. The preconsolidation stresses due to the specimen prepara-

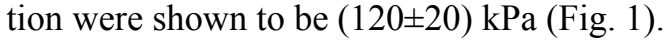

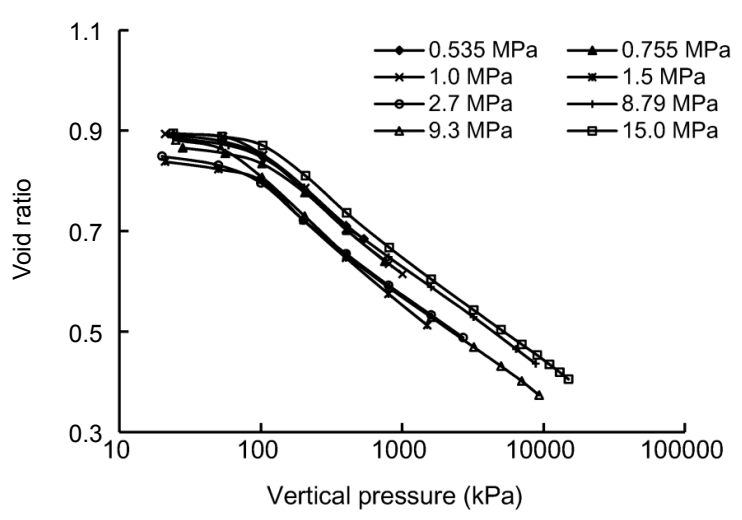

Fig. 1 Compression curves of the remolded deep clay

\subsection{Experimental program, triaxial apparatus, and test procedure}

CIUC tests on remolded deep clay specimens at seven different confining pressures were designed. The confining pressures in the program shown in Table 2 can be divided into three levels: level $1(<$ $1 \mathrm{MPa})$, level 2 (1-2 MPa), and level 3 (>2 MPa). Note that the lower limit of level 3,2 MPa, is equivalent to the consolidation stress at a depth of over $100 \mathrm{~m}$ in the thick overburden soil.

Table 2 shows that the minimum confining pressure is $0.3 \mathrm{MPa}$ which is 2.5 times the average pre-consolidation pressure of the specimens. It has been found that an isotropic pressure of only about 2.5-3.0 times the initial 1D consolidation pressure can erase the effect of fabric anisotropy formed during the 1D consolidation on the macroscopic stress-strain relations (Anandarajah, 2000). Accordingly, the effect of the fabric anisotropy developing during specimen preparation, as described in the last subsection, can be regarded as negligible. Therefore, all the consolidated specimens in this study are the isotropically normally consolidated ones.

Table 2 Triaxial shearing experimental program of CIUC tests

\begin{tabular}{cc||cc}
\hline Level & $\begin{array}{c}\text { Confining } \\
\text { pressure (MPa) }\end{array}$ & Level & $\begin{array}{c}\text { Confining } \\
\text { pressure (MPa) }\end{array}$ \\
\hline 1 & 0.3 & 2 & 1.0 \\
& 0.4 & & 1.2 \\
3 & 0.8 & 1.4 \\
\hline
\end{tabular}

Two triaxial apparatuses were used. The first one (TSZ30-2.0, made by the Nanjing Geotechnical Instrument Factory) is suitable for tests at a confining pressure below $2 \mathrm{MPa}$, and the second one (TATW-500, developed by the China University of Mining and Technology) is applicable to tests at higher confining pressures. The conventional standard frictional end platens and measurement of pore pressure at the bottom of the specimens were adopted in these triaxial apparatuses.

Only when the measured pore pressure parameter $B=\Delta u / \Delta \sigma_{3}$ was larger than 0.98 , in which $\Delta u$ is the change in the specimen pore pressure and $\Delta \sigma_{3}$ is the change in the confining pressure, were the soil specimens consolidated isotropically at a specific confining pressure with drainage allowed from the top of the specimen until the pore pressure measured at the base became stable. Then undrained shear tests were performed using a constant strain rate of $2.7 \% / \mathrm{h}$ which is slightly lower than that determined by the Chinese Standard method for soil testing (MWR, 1999b). This rate can be recognized to be slow enough to fully redistribute the pore water pressure in the specimens during shearing as follows.

An approximate theoretical strain rate which is sufficiently slow for the pore pressures across the specimen with fully effective drains (using filter strips) to reach $95 \%$ equalization ${ }^{1}$ can be estimated by

\footnotetext{
${ }^{1}$ The degree of equalization is $\left(1-p / p_{0}\right)$, where $p_{0}$ is the difference in pore pressure between the middle and ends of the specimen at a given strain with no redistribution, and $p$ is the difference in a test taking a time $t$ to reach this strain (Bishop and Henkel, 1962)
} 
the following equation (Germaine and Ladd, 1988; Bishop and Henkel, 1962):

$$
\dot{\varepsilon}=\frac{\varepsilon_{\mathrm{f}}}{0.07 h^{2} / C_{\mathrm{b}}},
$$

where $\varepsilon_{\mathrm{f}}$ is the axial strain at failure, $h$ is the $1 / 2$ height of the specimen, and $C_{\mathrm{b}}$ can be taken from oedometer data although it is not strictly equal to the coefficient of normal consolidation $C_{\mathrm{v}}$ from an oedometer test (Germaine and Ladd, 1988). The shear strain rate calculated by Eq. (1) for consolidation pressure of $0.4 \mathrm{MPa}$ and $2.6 \mathrm{MPa}$ is $6 \% / \mathrm{h}$ and $2.98 \% / \mathrm{h}$, respectively $\left(\varepsilon_{\mathrm{f}}\right.$ is $20 \%$ and $C_{\mathrm{v}}$ varies between $0.014 \mathrm{~cm}^{2} / \mathrm{min}$ and $0.0068 \mathrm{~cm}^{2} / \mathrm{min}$ for consolidation pressures of between $0.4 \mathrm{MPa}$ and $2.6 \mathrm{MPa}$, which have been obtained from 1D consolidation tests on the deep clay). Therefore, only minor nonuniformity in the pore pressure was produced across the deep clay specimens during the tests with the actual shear strain rate of $2.9 \% / \mathrm{h}$.

Note that standard frictional ends and the axial strain rate of $2.9 \% / \mathrm{h}$ were adopted in all the tests listed in Table 2 since the aim of this study is to investigate the effect of confining the pressure level.

\section{Results and discussion}

Stress strain curves, presented in Figs. 2-4, are of deviatoric stress $q$ which is defined as $\sigma_{1}-\sigma_{3}$, where $\sigma_{1}$ and $\sigma_{3}$ are the normal stress in the axial and radial directions, respectively, $u$ is the pore pressure, and $q / p^{\prime}$ is the stress ratio, in which $p^{\prime}$ is the mean effective stress and is defined as $\left(\sigma_{1}+2 \sigma_{3}\right) / 3-u$. Note that the confining pressure in the level 3 listed in Table 2 had been expected to be $3.6 \mathrm{MPa}$, but the actual confining pressure was $2.6 \mathrm{MPa}$ because the dissipation of pore pressure during consolidation was too timeconsuming for TATW-500. The other level-3 test in the original experimental program whose confining pressure was 4.5 MPa failed due to the inevitable leakage through the membrane increasing with test time. However, the shear plane observed in the specimen consolidated to $4.5 \mathrm{MPa}$ was well preserved and has been examined by an environmental scanning electron microscope (ESEM). To gain a better understanding of the difference of stress-strain-strength behavior of the deep clay in East China, the test results in this study have been compared with those of the clays mentioned in Section 1.

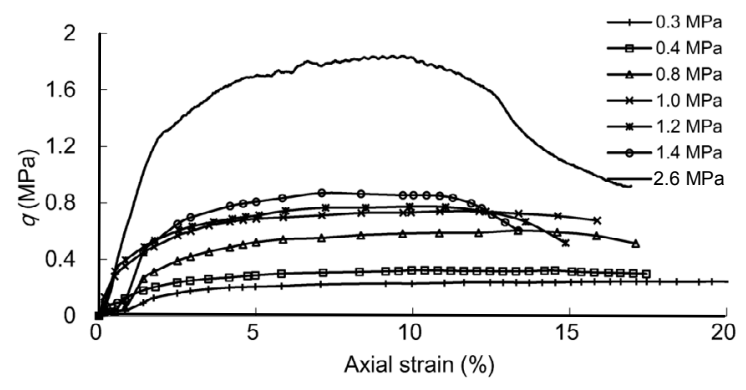

Fig. 2 Changes in deviatoric stress with axial strain

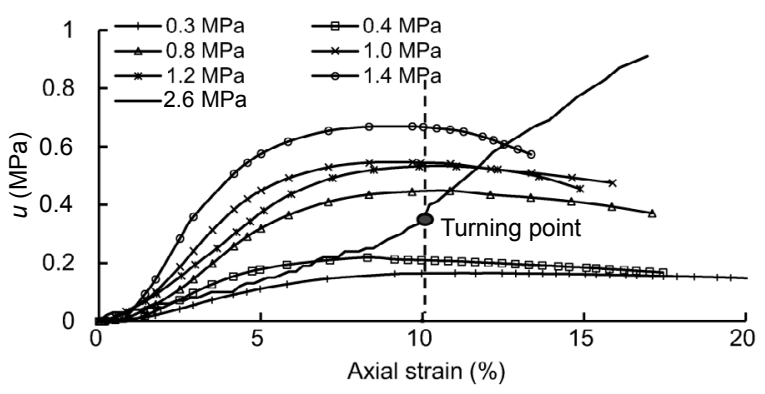

Fig. 3 Changes in pore pressure with axial strain

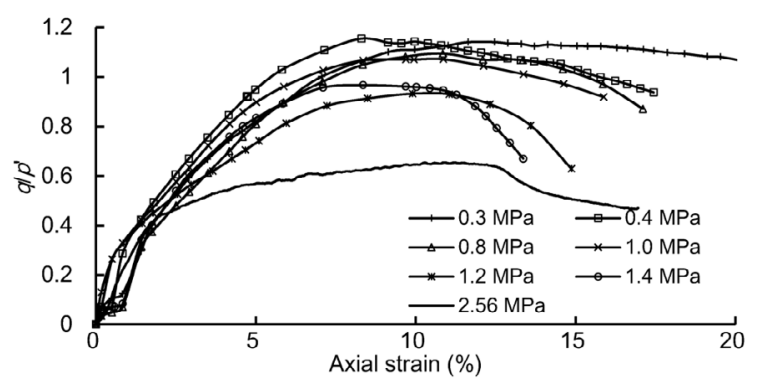

Fig. 4 Changes in stress ratio with axial strain

\subsection{Shear stress-strain behavior}

It can be observed from Fig. 2 that the stress-strain curves for the tests with consolidation pressures not larger than $1 \mathrm{MPa}$ represent the typical stress-strain behavior of normally consolidated clays. However, the stress-strain curves for the consolidation pressures larger than $1 \mathrm{MPa}$ in Fig. 2 are different and can be characterized by the ductile yielding and broad peak strength phase followed by a noticeable drop in the strength at axial strain larger than $11 \%$, and it seems that the drop is more significant in the case of higher consolidation pressure.

The reason for the above post-peak drop in strength is that the strength loss due to particle 
reorientation around the shear plane during shear exceeds the strength gain due to consolidation. This holds true even for normally consolidated clays (Mitchell and Soga, 2005). This drop will transform the specimens to their residual state. However, because the shear displacements required to reach the residual state can be very large (Wood, 1990; Mitchell and Soga, 2005), the specimens at consolidation pressures larger than $1 \mathrm{MPa}$ shown in Fig. 2 did not reach their final residual state at which the strength should be an asymptotic value.

Whether the clay specimen reaches its residual state depends on whether a smooth and continuous failure surface is formed through the specimen (Wood, 1990). Fig. 5 shows that apparent failure planes can be observed in specimens isotropically normally consolidated to pressure above $1 \mathrm{MPa}$, while the failure mode in the lower pressure tests is a bulging of the specimens. ESEM observation in Fig. 6 presents the polished and slicken-sided failure surface of specimens at high consolidation pressure. These observations confirmed that the post-peak drop in strength shown in Fig. 2 is part of the process in which the specimen is transformed to its residual state.

Skempton (1985) indicated that the drop in strength from peak to residual increases with the clay content in soils. It has also been shown that post-peak loss of the strength of cement-treated clay is larger than that of untreated clay (Kamruzzaman et al., 2009). Cementation is related to the shear strength of the soil and is a possible source of cohesion. Electrostatic and electromagnetic attraction between clay particles are the other source of cohesion (Mitchell and Soga, 2005). We have examined the pore fluid chemistry of the remolded deep clay. The top two cations in the pore fluid of the mixture of air-dried deep clay and distilled water are $\mathrm{Na}^{+}$and $\mathrm{Ca}^{2+}$ $(43.83 \mathrm{mg} / \mathrm{L}$ and $24.09 \mathrm{mg} / \mathrm{L}$, respectively). This is consistent with the nature of $\mathrm{Na}^{+}-\mathrm{Ca}^{2+}$ montmorillonite in the deep clay which has been shown in Table 1. The top two anions in the pore fluid are $\mathrm{Cl}^{-}$and $\mathrm{SO}_{4}{ }^{2-}$ $(95.53 \mathrm{mg} / \mathrm{L}$ and $153.02 \mathrm{mg} / \mathrm{L}$, respectively). Therefore, there would be chemical bonding between clay particles, and the strength of this bonding would increase over time. Since a longer time was needed for the high pressure consolidation process, the degree of cementation in the clay specimen consolidated at high

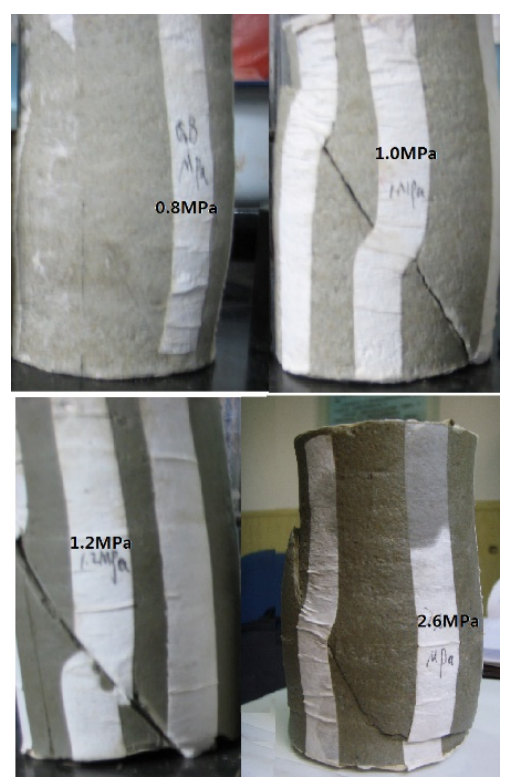

Fig. 5 Clay specimens after CIUC tests

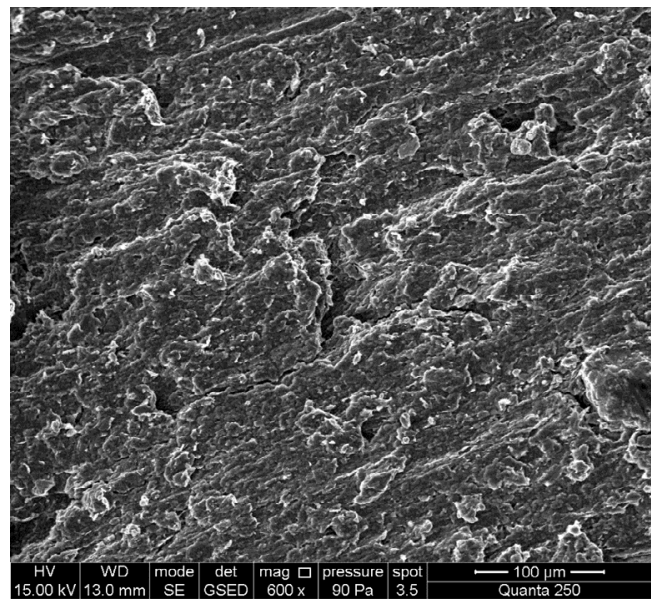

Fig. 6 ESEM micrograph of the failure surface in the specimen consolidated to $4.5 \mathrm{MPa}$

pressure would be higher than that at low pressure. On the other hand, electrostatic and electromagnetic attractions become significant only when the separation distance between clay particles is small. This is the case for the specimens consolidated at high pressure. To verify the above analysis, a series of direct shear tests have been carried out on the studied clay specimens subjected to consolidation stress in the range of 0.53-15.3 MPa. The details are not presented here for reasons of space. Fig. 7 shows that the cohesion exists only when the consolidation pressure is larger than approximately 1.6 MPa. The nonlinear strength envelope shown in this figure will be discussed in the next section in detail. Based on the aforementioned 
studies (Skempton, 1985; Kamruzzaman et al., 2009) and the above analysis, it can be stated that the cohesion between clay particles would contribute to the post-peak loss of strength.

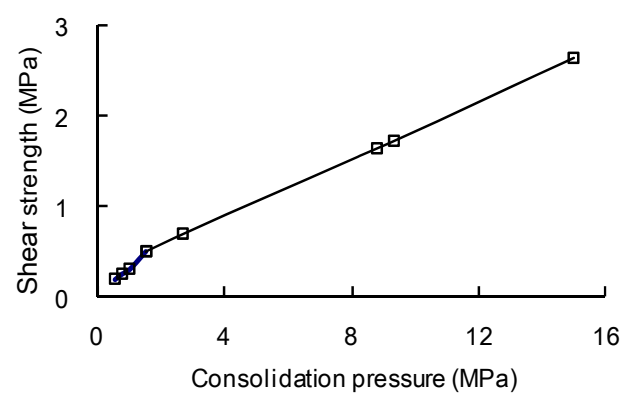

Fig. 7 Strength envelope obtained from direct shear tests on the studied clays

Another observation is that the axial strain at which peak deviatoric stress was reached $\left(\varepsilon_{\mathrm{f}}\right)$ decreases with increasing consolidation pressure (Fig. 8). Similar findings can be seen in the test data of both XZ clay (Zhou, 2009) and RBM (Graham et al., 1990). This is likely to be related to the increasing cementation between clay particles with the consolidation pressure as mentioned above.

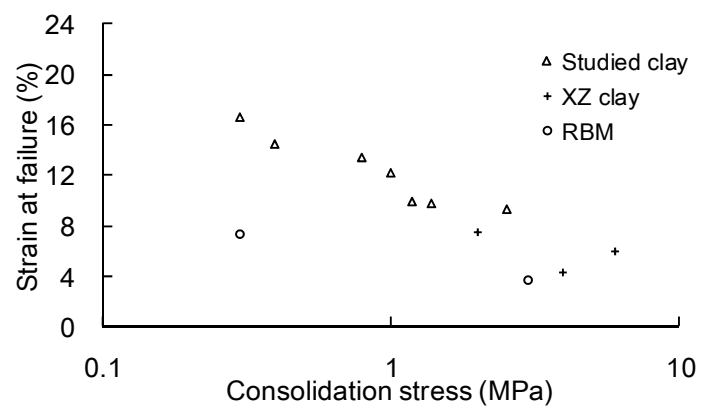

Fig. 8 Axial strain at failure as a function of consolidation stress for CIUC tests on chosen clays

\subsection{Shear strength}

Fig. 4 presents the evolution of the stress ratio $\left(q / p^{\prime}\right)$ during shearing the deep clay. It can be seen that the peak stress ratios broadly decrease as consolidation pressure increases. Fig. 9 summarizes the results of peak stress ratio as a function of consolidation stress for the deep clay, XZ clay (Zhou, 2009), RBM (Graham et al., 1990) and RBBC (Abdulhadi et al., 2012). It can be seen that the peak stress ratio decreases with increasing consolidation pressure for all four clays, and the decrease is much less for RBBC than those for the other three. In particular, for the studied clay, the peak stress ratio is almost a constant when the consolidation pressure is lower than $1 \mathrm{MPa}$, and decreases significantly for consolidation pressures higher than $1 \mathrm{MPa}$. This is broadly consistent with the strength envelope shown in Fig. 7 which consists of two linear segments and was obtained from direct shear tests on the clay. From the aforementioned definition of the stress ratio, it can be seen that peak stress ratio is an effective strength parameter.

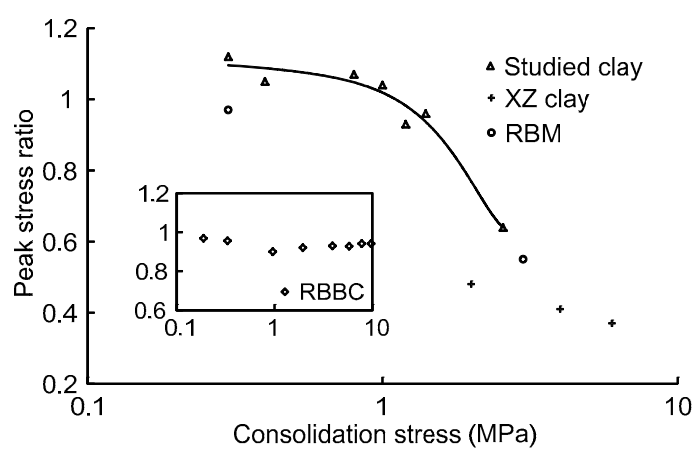

Fig. 9 Peak stress ratio as a function of consolidation stress for undrained triaxial compression tests on chosen clays

End friction and axial strain rate have little effect on the effective strength parameters (Hight, 1982), especially for normally consolidated soil (Germaine and Ladd, 1988). Moreover, the end platen and axial strain rate in the tests are the same for each one of the four clays. Therefore, the stress-dependent peak shear ratio for the studied clay should be an inherent soil property. A possible explanation of this stressdependent peak shear ratio is as follows. For the clay specimens at low consolidation pressures, local particle reorientation is not evident so that there is no noticeable shear plane (Fig. 5). Therefore, the frictional part of the shear resistance at low pressures is dominated by the direct friction between non-parallel solid particles. However, in the case of higher consolidation pressures, intense local particle reorientation leads to an apparent shear plane (Fig. 5). In particular, the particles in and near the shear plane shown in Fig. 6 are approximately parallel to the plane. Similar observations have been reported (Hicher et $a l ., 2000)$. In such a case, the electrochemical repulsive stresses due to the overlaps of the diffuse double layer of neighbor parallel clay particles will take a larger proportion of the total effective stress in the 
specimens with closer separation distance between clay particles (Graham et al., 1992). Accordingly, the amount of the mechanical contacts between solid clay particles decreases markedly and the frictional shear resistance of clay specimens at high pressures is almost dominated by the shear resistance of the adsorbed water between the packed parallel clay particles. The shear resistance of the adsorbed water is smaller than that between solid clay particles. As a result, the peak shear stress ratio at low pressure is larger than that at high pressure (Fig. 9). The approximately linear relation between the void ratio (which reflects the distance between clay particles) and the peak stress ratio for the tests at consolidation pressures above $0.8 \mathrm{MPa}$ presented in Fig. 10 partially supports the above analysis.

Similarly, the distance and degree of the parallelism between clay particles of one-dimensionally normally compressed clay specimens at lower pressure, which was used in the direct shear tests, are larger and higher than those at higher pressure. Thus, the nonlinear frictional angle shown in Fig. 7 can be interpreted well using the above analysis.

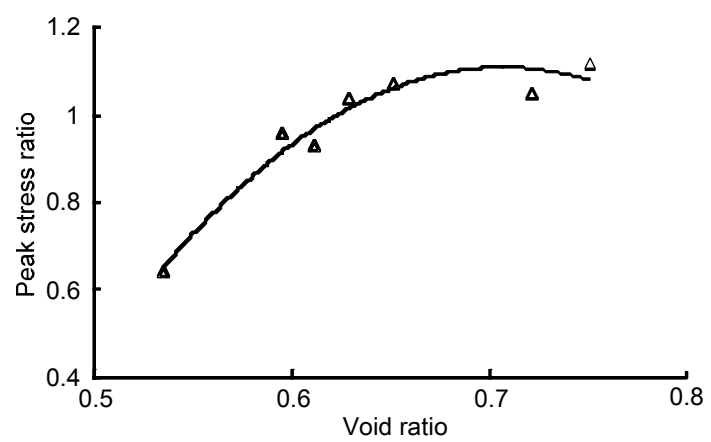

Fig. 10 Peak stress ratio as a function of void ratio for the studied clay

\subsection{Pore pressure}

It can be seen from Fig. 3 that the relationship between pore pressure and axial strain for the $2.6 \mathrm{MPa}$ test on the studied clay is significantly different from the others which basically represent the typical pore pressure behavior of normally consolidated clays. In the 2.6 MPa test, the pore pressure increased slowly until the axial strain was up to around $10 \%$ (the turning point shown in Fig. 3) and then increased quickly towards the end of the test. Similar observations have been obtained in the CIUC tests on XZ clay and sandy XZ clay (Fig. 11) at high consolidation pressures (Zhou, 2009). The similarity in the stress-dependent pore pressure-strain behavior between the deep clay and XZ clay is likely to be due to the fact that the major mineral ingredient in both of them is smectite, as shown in Table 1.

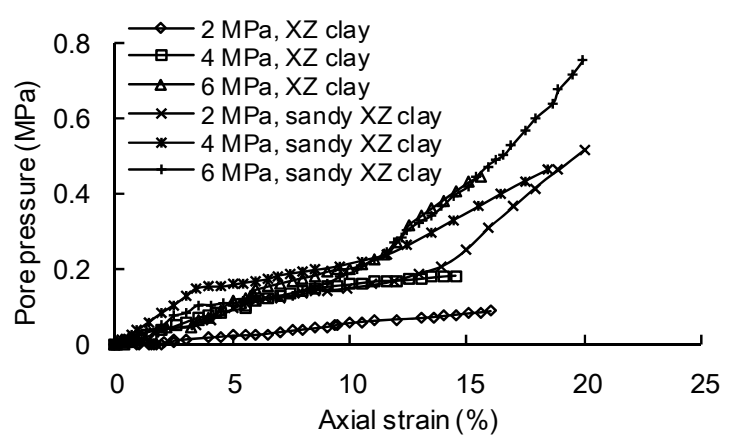

Fig. 11 Variations of pore pressure of XZ clay and sandy XZ clay (Zhou, 2009)

Graham et al. (1990) revealed that the pore pressure increased slowly until the end of the test on the RBM specimen consolidated to $3 \mathrm{MPa}$, while there was a significant decrease in the pore pressure during the test with a consolidation pressure of 0.2 MPa. This difference is believed to be attributable to the overconsolidation of compacted RBM specimens at low consolidation pressure.

However, the stress-dependent pore pressurestrain behavior of the studied clay as shown in Fig. 3 would not result from the possible overconsolidation since all the specimens in this study were normally consolidated. A possible explanation of this stressdependent behavior is given below.

Marcial et al. (2002) investigated the compressibility of bentonite and indicated that the compression at lower stress was due to the extrusion of water molecules inside larger inter-aggregate or interdomain pores while the extrusion of adsorbed water located within the clay domains resulted in lower compressibility at high consolidation stress. A previous study on the studied deep clays has also confirmed that adsorbed water occupies most of the pore space in the clay specimens at consolidation pressures larger than around $2 \mathrm{MPa}$ and the associated specimens are less compressive (Shang et al., 2015).

Accordingly, inter-aggregate or inter-domain water molecules are likely to be only a small part of the total pore water in the studied clay specimen 
consolidated at high pressure, while the intra-domain water molecules are the major part. Consequently, the specimens consolidated at high pressure above $2 \mathrm{MPa}$ are less compressive during undrained shear than those at low pressure. Therefore, the pore pressure increases quite slowly during the early stage of undrained shear. When the shear strain is large enough (e.g., 10\%), an obvious shear surface forms which usually intersects with the base platen in triaxial devices. Because the clay platelets near the shear surface experience intensive reorientation and tend to be parallel to the plane (Bai and Smart, 1997; Hicher et al., 2000), a great deal of intra-domain water between the clay platelets will be extruded. As a result, the pore pressure measured at the base increases quickly at an axial strain over 10\% as shown in Figs. 3 and 11. However, in the case of low consolidation pressure, the intra-domain water is a minor part, and thus will not affect the pore pressure measured at the base significantly even though there exists an obvious shear plane in specimens. The ESEM graph shown in Fig. 12 presents the view of micro clay platelets on the shear plane of the studied clay specimen which was isotropically consolidated to $4.5 \mathrm{MPa}$. Fig. $12 \mathrm{~b}$ is the magnification of the image enclosed in the wireframe in Fig. 12 a, and so on. The magnifications of Figs. 12a-12d are 1200, 2400, 5000, and 10000, respectively. It can be seen that many thin clay platelets in clay particles have curled up due to the intensive reorientation and the intra-domain space enclosed by the clay platelets became more open. A delamination of bentonite particles at large strain near the shear plane has been confirmed (Hicher et al., 2000). Therefore, it is reasonable to deduce that the intra-domain water residing in the shear plane will be extruded at large strain.

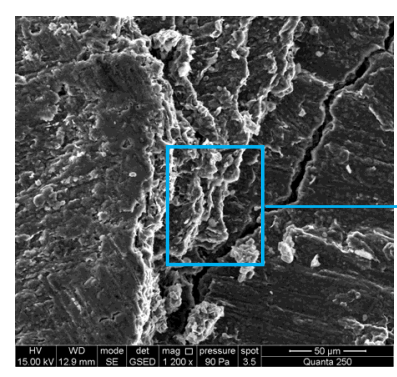

(a)

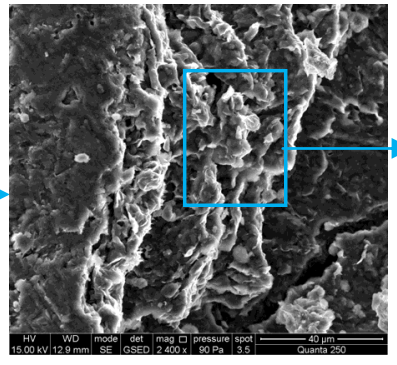

(b)

\subsection{Discussions in terms of critical state soil mechanics}

Fig. 13 presents the effective stress path in the $p^{\prime}-q$ plane during undrained shear on the studied clay specimens, in which the dashed line denotes the critical state line. Fig. 14 presents the normal consolidation lines (NCL) and peak strength lines (PSL) of the studied clay and XZ clay (Zhou, 2009), in which $v$ denotes the specific volume, and the effective mean stress and associated specific volume corresponding to the points on PSL are evaluated at peak stress ratios.

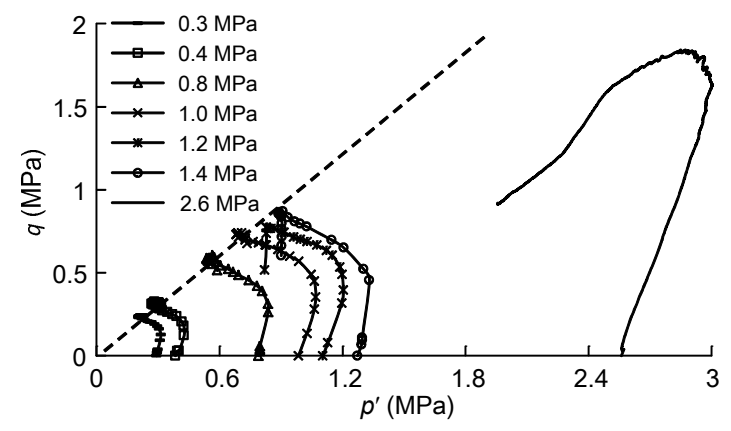

Fig. 13 Effective stress path during shear in CIUC tests on the studied clay

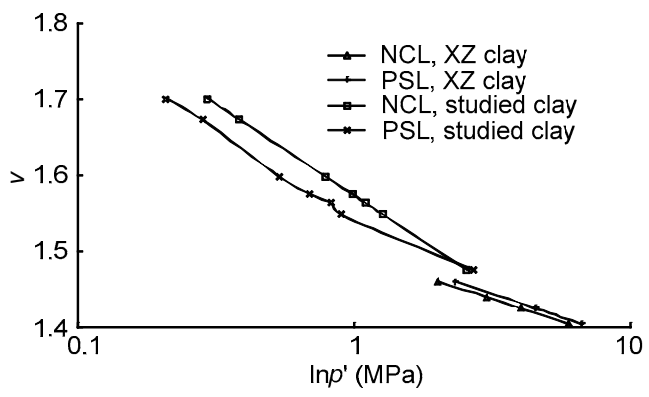

Fig. 14 NCL and PSL against consolidation pressure for chosen clays

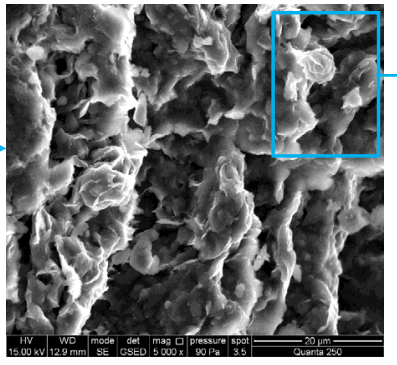

(c)

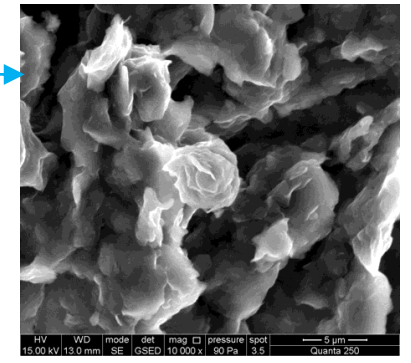

(d)

Fig. 12 ESEM micrograph of the shear surface in the studied clay specimen consolidated to $4.5 \mathrm{MPa}$ Magnifications of (a)-(d) are 1200, 2400, 5000, and 10000, respectively 
Considering that peak strength state of normally consolidated clay can be seen as an approximately critical state (Wood, 1990), all the peak strength states of the studied clays at consolidation pressures lower than $2 \mathrm{MPa}$ in the $p^{\prime}-q$ plane (Fig. 13) and in $v-\ln p^{\prime}$ plane (Fig. 14) show the typical features of the critical state of normally consolidated clays.

The only exception is the test on studied clay at consolidation pressure of $2.6 \mathrm{MPa}$. According to Wood (1990), the condition of the critical state can be expressed by

$$
\frac{\partial p^{\prime}}{\partial \varepsilon_{\mathrm{a}}}=\frac{\partial q}{\partial \varepsilon_{\mathrm{a}}}=\frac{\partial v}{\partial \varepsilon_{\mathrm{a}}}=\frac{\partial u}{\partial \varepsilon_{\mathrm{a}}}=0
$$

where $\varepsilon_{\mathrm{a}}$ is the axial strain. In the case of the test at 2.6 MPa, $p^{\prime}$ changed constantly during shear (Fig. 13) since the corresponding pore pressure shown in Fig. 3 increased unceasingly. In addition, its PSL almost intersects with NCL. The same is true for the XZ clay. Accordingly, for the specimen consolidated at 2.6 MPa, its critical state seems not to be reached. In fact, as mentioned in Section 3.3, the measured pore pressure from 2.6 MPa test was related to localized shear plane. Therefore, the unusual pore pressure response shown in Fig. 3 could not represent the real mechanical behavior of the soil specimen which is assumed to be a uniform element in triaxial tests. As a result, the test curves corresponding to $2.6 \mathrm{MPa}$ consolidation pressure shown in Figs. 13 and 14 cannot properly be used to identify the critical state of the studied clay specimens.

In addition, the effective stress paths of isotropically normally compressed specimens during undrained shear should slope to the left in order to balance the shear-reduced compressive plastic volumetric strain according to the modified cam clay model (Wood, 1990). Therefore, the effective stress path of the studied clay specimens should have sloped to the left in Fig. 13. Inspection of the pore water pressurestrain relations presented in Fig. 3 indicates that all except the case of $2.6 \mathrm{MPa}$ show that the measured pore water pressure (first 5-6 data points) related to an axial strain smaller than $1.5 \%$ increased with axial strain too slowly to be not credible. The early parts of the effective stress paths shown in Fig. 13 exactly correspond to these data points at which the pore water pressures were likely to be underestimated so that the magnitude of $p^{\prime}$ was overestimated. Consequently, the early parts of the stress paths tend to slope to the right. For the test at $2.6 \mathrm{MPa}$ which was conducted using the triaxial apparatus TATW-500 (while the other tests were carried out based on TSZ30-2.0) there was no such correspondence. Although the possible explanation of the pore water pressure-strain relation of the $2.6 \mathrm{MPa}$ test has been explored in the previous subsection, the reason for the unusual slope of the effective stress path of $2.6 \mathrm{MPa}$ is not yet fully understood and further study is needed.

\section{Conclusions}

In this paper, CIUC behaviors of the reconstituted deep clay at a wide range of consolidation pressures have been investigated. Test results show that consolidation pressure has a significant effect on the stress-strain-strength properties of the clay. Post-peak drop in strength and shear planes are increasingly evident with increasing consolidation pressure. Peak stress ratio and the axial strain at which peak stress ratio was reached decrease with increasing consolidation pressure. In the case of high consolidation pressure above $2 \mathrm{MPa}$, the pore pressure increases slowly in the early stage of undrained shear (axial strain smaller than 10\%) and then increases quickly towards the end of the test. However, the pore pressure response for low consolidation pressure shows a typical behavior of normally consolidated clay.

The micro mechanisms underlying the lower peak stress ratio and unusual pore pressure response in the case of higher consolidation pressure have been shown to be closely correlated to the changes in the microstructure of clay specimens during shear. In addition, the critical state of the studied clay at high consolidation pressure above $2 \mathrm{MPa}$ is difficult to reach in the undrained shear test.

\section{Acknowledgements}

Special thanks are due to the reviewers for their suggestions, which have greatly improved the paper. In addition, the 
first author would like to express his sincere thanks to the Advanced Analysis \& Computation Center at China University of Mining \& Technology for the ESEM tests.

\section{References}

Abdulhadi, N.O., Germaine, J.T., Whittle, A.J., 2012. Stressdependent behavior of saturated clay. Canadian Geotechnical Journal, 49(8):907-916. [doi:10.1139/t2012-057]

Anandarajah, A., 2000. On influence of fabric anisotropy on the stress-strain behavior of clays. Computers \& Geotechnics, 27(1):1-17. [doi:10.1016/S0266-352X(00)00005-7]

Bai, X., Smart, P., 1997. Change in microstructure of kaolin in consolidation and undrained shear. Geotechnique, 47(5): 1009-1017. [doi:10.1680/geot.1997.47.5.1009]

Bishop, A.W., Henkel, D.J., 1962. The Measurement of Soil Properties in the Triaxial Test, 2nd Edition. Edward Arnold, London.

Cui, G.X., 2003. Loading of shaft lining for deep alluvium. Chinese Journal of Geotechnical Engineering, 25(3): 294-298 (in Chinese). [doi:10.3321/j.issn:1000-4548. 2003.03.009]

Germaine, J.T., Ladd, C.C., 1988. State-of-the-art paper: triaxial testing methods of saturated cohesive soils. In: Donaghe, R.T., Chaney, R.C., Silver, M.L. (Eds.), Advanced Triaxial Testing of Soil and Rock, ASTM STP 977, ASTM, Philadelphia, p.421-459. [doi:10.1520/STP 977-EB]

Graham, J., Saadat, F., Gray, M.N., 1990. High-pressure triaxial testing on the Canadian reference buffer material. Engineering Geology, 28(3-4):391-403. [doi:10.1016/00137952(90)90023-T]

Graham, J., Oswell, J.M., Gray, M.N., 1992. The effective stress concept in saturated sand-clay buffer. Canadian Geotechnical Journal, 29(6):1033-1043. [doi:10.1139/t92 -121]

Hicher, P.Y., Wahyudi, D., Tessier, D., 2000. Microstructural analysis of inherent and induced anisotropy in clay. Mechanics of Cohesive-Frictional Materials, 5(5):341-371. [doi:10.1002/1099-1484(200007)5:5<341::AID-CFM99> 3.0.CO;2-C]

Hight, D.W., 1982. A simple piezometer probe for the routine measurement of pore pressure in triaxial tests on saturated soils. Geotechnique, 32(4):396-401. [doi:10.1680/geot. 1982.32.4.396]

Kamruzzaman, A.H.M., Chew, S.H., Lee, F.H., 2009. Structuration and destructuration behavior of cement-treated Singapore marine clay. Journal of Geotechnical and Geoenvironmental Engineering, 135(4):573-589. [doi:10. 1061/(ASCE)1090-0241(2009)135:4(573)]

Li, W.P., Li, X.Q., 2005. Mechanism of rupture of shaft linings in coal mine areas buried by thick over-soils in East China. Geotechnique, 55(3):237-244. [doi:10.1680/geot.2005. 55.3.237]

Ma, J.R., Qin, Y., Zhou, G.Q., 2008. Research on triaxial shear properties of clay under high pressures. Journal of China University of Mining and Technology, 37(2):176-179 (in Chinese). [doi:10.3321/j.issn:1000-1964.2008.02.007]

Marcial, D., Delage, P., Cui, Y.J., 2002. On the high stress compression of bentonites. Canadian Geotechnical Journal, 39(4):812-820. [doi:10.1139/t02-019]

Mitchell, J., Soga, K., 2005. Fundamentals of Soil Behavior. John Wiley \& Sons, New Jersey.

MWR (Ministry of Water Resources), 1999a. Specification of Soil Tests, SL 237-1999. National Standards of People's Republic of China (in Chinese)

MWR (Ministry of Water Resources), 1999b. Standard for Soil test Method, GB/T 50123-1999. National Standards of People's Republic of China (in Chinese).

Schofield, A.N., Wroth, C.P., 1968. Critical State Soil Mechanics. Pergamon Press, Oxford.

Shang, X.Y., Zhou, G.Q., Kuang, L.F., et al., 2015. Compressibility of deep clay in East China subjected to a wide range of consolidation stresses. Canadian Geotechnical Journal, 52(2):244-250. [doi:10.1139/cgj-2014-0129]

Skempton, A.W., 1985. Residual strength of clays in landslides, folded strata and the laboratory. Geotechnique, 35(1):3-18. [doi:10.1680/geot.1985.35.1.3]

Wood, D.M., 1990. Soil Behaviour and Critical State Soil Mechanics. Cambridge University Press, Cambridge.

Xu, Y.C., 2004. Mechanics characteristics of deep saturated clay. Journal of China Coal Society, 29(1):27-30 (in Chinese). [doi:10.3321/j.issn:0253-9993.2004.01.006]

Zhang, Z.M., 2011. Achievements and problems of geotechnical engineering investigation in China. Journal of Zhejiang University-SCIENCE A (Applied Physics \& Engineering), 12(2):87-102. [doi:10.1631/jzus.A1000433]

Zhao, X.D., Zhou, G.Q., Wang, B., 2009. Study of the stress paths tests for the deep reconstituted soils at high pressure. Journal of China University of Mining and Technology, 38(4):471-475 (in Chinese). [doi:10.3321/j.issn:10001964.2009.04.004]

Zhou, L.Z., 2009. Study on Stress-path Behavior of Cohesive Soil under High Triaxial Pressure and Its Application. MS Thesis, China University of Mining and Technology, Xuzhou, China (in Chinese).

\section{中文概要}

题 目: 华东深部重塑粘土不排水剪切行为的压力相关性

目 的：研究固结应力水平对深部重塑粘土不排水剪切行 为的影响, 着重分析高、低固结压力作用下黏土 力学响应的差异, 并揭示这种影响和差异的内在 机理。

创新点：1. 揭示重塑黏土的固结不排水剪切应力应变行为 显著依赖固结应力水平的特点; 2 . 发现上述与应 
力水平相关的应力应变响应与黏土微观结构等 密切相关。

方 法: 1. 开展重塑深部黏土不同压力水平下（表 2) 的 三轴等向固结不排水剪切试验; 2. 利用环境扫描 电镜获得的颗粒结构特征, 从微观结构角度揭示 与压力相关的应力-应变、强度与孔隙水压响应的 内在机理; 3. 在临界土力学框架内讨论高压下重 塑深部黏土的临界状态特征（图 13 和 14)。

结 论：1. 固结压力水平对重塑黏土的应力-应变-强度特 性有显著影响; 2. 随着固结压力的增加, 软化现
象和局部剪切带逐渐明显 (图 2 和 5), 峰值应力 以及相应轴向应变则不断减小 (图 8 和 9); 3 . 在 大于 $2 \mathrm{MPa}$ 的高压固结不排水试验中, 其孔隙 水压/轴向应变曲线明显不同于常压 (图 3); 4. 上 述与压力相关的力学性质均与黏土微观结构相关

(图 6 和 12); 5. 高压下黏土难以达到所谓的临 界状态。

关键词: 深部粘土; 高压; 不排水三轴压缩剪切; 压力相 关性 